\title{
TITLE:
}

\section{ASTEROIDEA OF THE SECOND JAPANESE ANTARCTIC RESEARCH EXPEDITION (1957-1958)}

\author{
$\operatorname{AUTHOR}(\mathrm{S})$ :
}

Hayashi, Ryoji

\section{CITATION:}

Hayashi, Ryoji. ASTEROIDEA OF THE SECOND JAPANESE ANTARCTIC RESEARCH

EXPEDITION (1957-1958). SPECIAL PUBLICATIONS FROM THE SETO MARINE BIOLOGICAL LABORATORY 1961, 1(16): 1-8

\section{ISSUE DATE:}

1961-12

URL:

http://hdl.handle.net/2433/176446

RIGHT: 
SPECIAL PUBLICATIONS FROM THE SETO MARINE BIOLOGICAL LABORATORY

BIOLOGICAL RESULTS

$\mathrm{OF}$

THE JAPANESE ANTARCTIC RESEARCH EXPEDITION

16.

\section{ASTEROIDEA OF THE SECOND JAPANESE ANTARCTIC RESEARCH EXPEDITION (1957-1958)}

BY

\section{RYOJI HAYASHI}

BTOLOGICAL, INSTITUTE, TOYAMA UNIVERSITY TOYAMA, JAPAN

SIRAHAMA, WAKAYAMA-KEN

JAPAN

DECEMBER 1961 
SPECIAL PUBLICATIONS FROM THE: SETO MARINE BIOLOGICAL LABORATORY

\author{
BIOLOGICAL RESULTS \\ $\mathrm{OF}$
}

THE JAPANESE ANTARCTIC RESEARCH EXPEDITION

16.

\title{
ASTEROIDEA OF THE SECOND JAPANESE ANTARCTIC RESEARCH EXPEDITION \\ (1957-1958)
}

BY

RYOJI HAYASHI

BIOLOGICAL INSTITUTE, TOYAMA UNIVERSITY TOYAMA, JAPAN

SIRAHAMA, WAKAYAMA-KEN

J A P A N

DECEMBER 1961 
This series contains THE BIOLOGICAL RESULTS OF THE JAPANESE ANTARCTIC RESEARCH EXPEDITION and is published by the Seto Marine Biological Laboratory. Parts will appear at irregular intervals as they become ready.

PRINTED IN JAPAN

BY NIPPONERPINTING AND PUBLISHING Co., Ltd. HUKUSIMA, OSAKA 
THE present paper is based on the Asteroids obtained by the Second Japanese Antarctic Research Expedition (1957-1958). It contains three species, one of them was collected by Dr. Chimaki Koyama who was a doctor to the second cruise and the other two were brought back by the cruise as a gift of a native school boy in Cape Town.

I must express my cordial thanks to Dr. Riozo Yosil of the Yoshida College, Kyoto University, for placing the specimens at my disposal, who was a biologist to the second cruise, and also to Dr. T. TokiokA of the Seto Marine Biological Laboratory for his kindness showed me to receive valuable literature.

\section{Odontaster validus KOEHLER}

(Pl. I, figs. 5, 6)

Odontaster validus: FISHER, 1940, p. 101.

Gnathaster validus: KoEHLER, 1920, p. 228 , pl. 34 , fig. 10 ; pl. 40, figs. 4, 5,7 ; pl. 41, figs. 2, 5 ; pl. 72 , fig. 3 .

Three specimens were examined. They are, however, exceedingly in unfavourable conditions. When I recieved them, almost all the spines of them had been already fallen off, and even the bodies softened unnaturally. So far as my observation goes, they are probably a form of a circumpolar species, Odontaster validus. The measurements are as follows:

$\begin{array}{rc}\mathrm{R} & \mathrm{r} \\ 15 \mathrm{~mm} & 7 \mathrm{~mm} \\ 18-10 \mathrm{~mm} & 9 \mathrm{~mm} \\ 19 \mathrm{~mm} & 9 \mathrm{~mm}\end{array}$

Body stellato-pentagonal in form, with large disc having curved interbrachial margin, rays rather short and slender. Dorsal integument thin, covered with distinct paxillae uniformly spaced. Owing to the unfavourable condition of material, the spinulation of paxillae was not ascertained, except the small interradial areas where some of the paxillae still remained completely. These spinelets are very short and fine, $0.32-0.35 \mathrm{~mm}$ long, 10 to 14 in number for each pexilla, forming a compact group. The central spinelets are not more robust than the peripherals as stated in O. meridionalis. Dorsal plates roundish in contour, but some of them somewhat lobulated. These plates are isolated or slightly touched by the bases or the lobes. In the surface view the pedicels 
of paxillae are arranged regularly in transverse series from the median line of ray obliquely forward. Papulae isolated, but never prominent, 5 or 6 around the base of the dorsal plate, except the small triangular interradial regions where seemingly absent.

Marginal plates paxilliform, rather easily distinguishable from the dorsal plates. The superomarginal plates are very slightly smaller than the opposite inferomarginals or about same as large as the latter. The pedicels of these plates are low and slightly compressed transversely. These paxillae seem to be slightly separated, each having a compact group of about 15 spinelets being slightly longer than in the dorsolateral paxillae. These spinelets measure 0.45 to $0.6 \mathrm{~mm}$ in length, and the central ones are acute, never clavate.

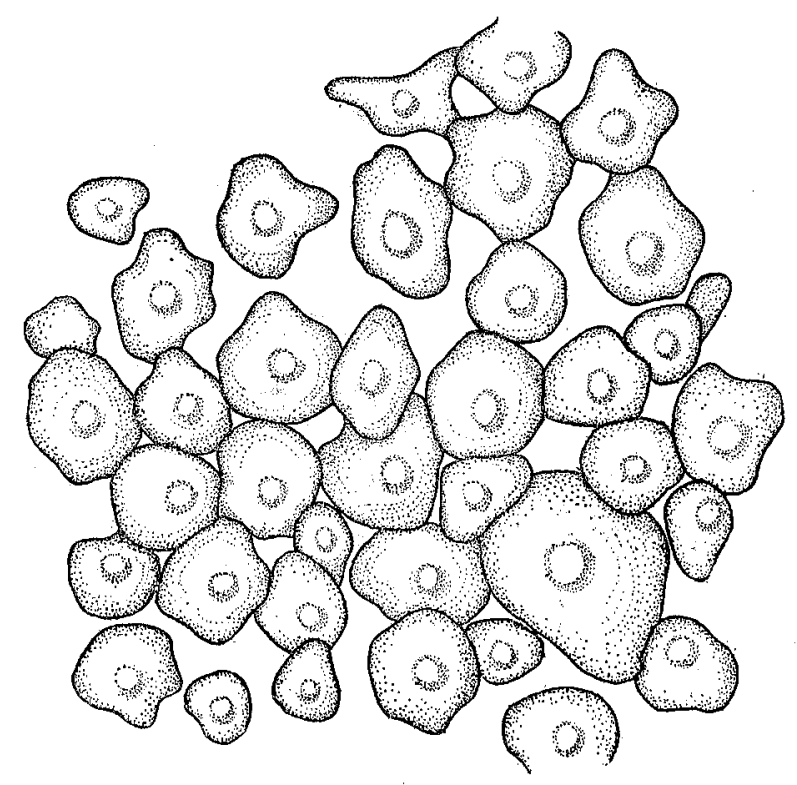

Fig. 1. Odontaster validus; a portion of dorsal skeleton. $20 \times$.

The ventral surface of body is perfectly flattened, and the interradial areas subtriangular in form. The ventrolateral plates are arranged in regular transverse and longitudinal series. The innermost series just outside of adambulacral plates extends a little beyond the three-fourths the length of ray, gradually decreasing in size distalward. The transverse series of the ventrolateral plates are each opposite to the adambulacral plate in the proximal portion of ray. The second longiseries is a little shorter than the first; the third reaches about one-half the length of ray; the fourth and fifth much shorter. These plates gradually become small outward, thus a wide triangular interradial area is 
Asteroidea of the Second Japanese Antarctic Research Expedition (1957-1958)

formed. The ventrolateral plates seem to be invested with 2 to 4 or 5 spinelets according to the size of plates. The spinelets are rather shorter than adambulacral spines, measuring $0.6-0.8 \mathrm{~mm}$ in length.

The adambulacral armature seems to be generally composed of 6 slender spines arranged in 2 transverse rows, none deep in furrow, the innermost spines measuring about $1.3 \mathrm{~m}$ in length. These spines slightly decrease in length outward. The armature of mouth plates is very characteristic. If the armature examined by me is in a complete condition, it is as follows: Along the furrow margin of the plate are found 5 small oral spines gradually increasing in length toward the jaw tip, the innermost being slightly stouter
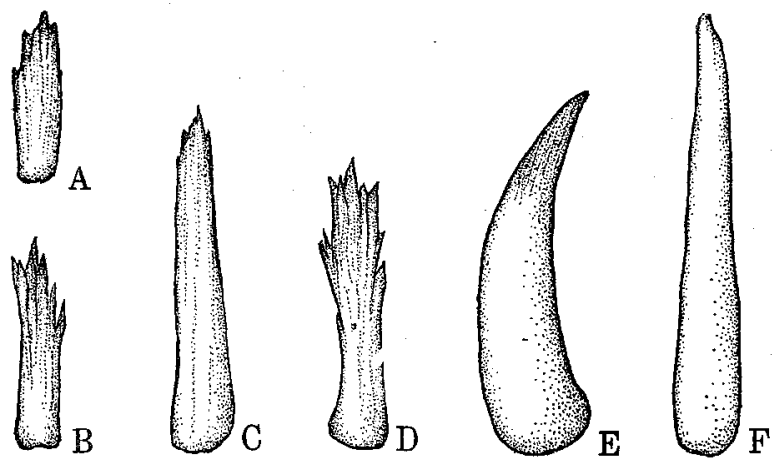

Fig. 2. Odontaster validus; A, B dorsal spines, $60 \times ; \mathrm{C}$ ventrolateral spine, $45 \times ; \mathrm{D}$ inferomarginal spine, $60 \times$; E oral spine, $20 \times ; \mathrm{F}$ adambulacral spine, $35 \times$.

than the rest. Just behind the series is situated the suboral series consisting of 2 or 3 similar spines. At the oral corner, just behind the 2 innermost spines of both the furrow series, is found a long, stout and curved spine on the median suture of the combined plates. The tip of the spine is pointed and glassy. The median suture is much wide and separated in the distal half portion.

Madreporite convex and nud, situated nearly midway between the centre of disc and the margin.

Loc. Luitzow-Holm Bay, Antarctic Sea.

Coll. Dr. Chimaki Koyama, I II, 1957.

\section{Asterina dyscrita CLARK}

(Pl. I., figs. 1, 2)

Asterina dyscrita: H. L. CLARK, 1923, p. 285, pl. 15, figs. 5, 6. 


\section{Ryoji HAỸAsì}

Four small Asterina were examined. The measurements are as follows:

$\begin{array}{rcc}\mathrm{R} & \mathrm{r} & \mathrm{R}: \mathrm{r} \\ 9 \mathrm{~mm} & 8 \mathrm{~mm} & 1.1 \\ 9.5 \mathrm{~mm} & 6 \mathrm{~mm} & 1.5 \\ 11 \mathrm{~mm} & 7 \mathrm{~mm} & 1.5 \\ 11.5 \mathrm{~mm} & 9 \mathrm{~mm} & 1.2\end{array}$

Judging from the excellent original description of H. L. CLARK ('23) these specimens are referable to be the present species having been reported from the South Africa. The form may be included in Patiriella according to VERRILL's revision of the group, but I will use here Asterina in its wide sense of that term.

Body subpentagonal in form, dorsal side much swollen, the ventral completely flattened. Dorsal skeleton composed of 2 kinds of plates. The principal plates are large, lunular, excavated for papluar areas and arranged in regular series. The carinal plates are slightly larger than the dorsolaterals forming inverted $\mathrm{V}$ with those of the adjacent ray. These plates are covered with coarse granule-like spinelets, each with 12 to 16 spinelets in the large plates. Those in carinal plates are arranged in somewhat 2 irregular transverse rows. The accessory plates are situated in papular areas. These plates are small, not numerous, 1 or 2 in an area, invested with 1 to 3 spinelets similar to those of the principal plates in form, but slightly smaller.

Marginal plates indistinct. There is a series of plates along the margin of disc, probably corresponding to the inferomarginal plates, each with 5 to 8 spinelets. Just above the series is found a similar series of plates, probably the representative of superomarginal plates, each with 4 to 6 spinelets.

Ventrolateral plates roundish or oval in form, imbricated, forming inverted $\mathrm{V}$ with those of the adjacent ray. These plates decrease in size toward the body margin. The ventrolaterals adjacent to adambulacral plates are spineless, but the remainder spinulose, each having a single spine except near the body margin where 2 spines generally occur. These spines decrease in size toward the body margin.

Furrow spines of adambulacral plates short and slender, 2 in number in the greater part of ray, except the proximal 3 to 5 plates having 3 . Subambulacral spines usually single, bluntly pointed, much longer and stouter than the furrow spines. Mouth plates each with 2 stout oral spines at the tip of jaw, the inner about twice as large as the outer. Being apart a little from the oral pair, rather deep in furrow, there are 3 to 5 short slender spines in a comb, probably corresponding to the furrow spines of adambulacral plates.

Madreporite subcircular in form, situated nearer the centre of disc than the margin.

Loc. Cape Town (A gift of a native school boy). 
Asteroidea of the Second Japanese Antarctic Research Expedition (1957-1958)

\section{Henricia $s p$.}

(PI. I, figs. 3, 4)

A single tiny specimen was examined, measuring only $8 \mathrm{~mm}$ in $\mathrm{R}, 3 \mathrm{~mm}$ in $r$. It is undoubtedly a form of Henricia and probably the young. Concerning the group having extraordinary variability, it may be quite difficult to identify the species without material enough. The present form may be related to $H$. simplex (SLADEN), but the young form of the species has not previously been reported by any authors. SLADEN's specimen measures $27 \mathrm{~mm}$ in $\mathrm{R}$ and FISHER's one $36 \mathrm{~mm}$. The specimen in my hand is too much tiny to compare with them. It resembles $H$. simplex in having a simple adambulacral armature and the absence of ventrolateral papulae, but in the present form the ventrolateral plates can not be observed and also the intermarginal papulae absent. In Henricia the intermarginal papulae may be occasionally formed later, but such a form lacking entirely ventrolateral plates is quite curious, though it may be

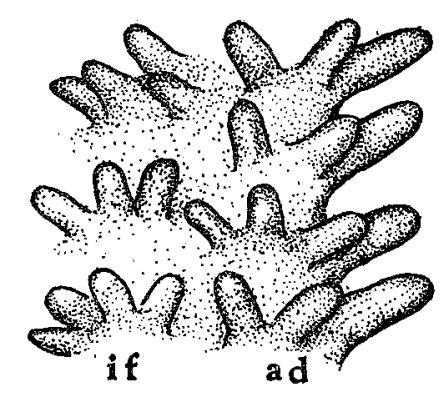

Fig. 3. Henricia sp.; a portion of adambulacral armature, $25 \times$; ad adambulacral spines, if inferomarginal spines.

a junior form. Regarding the dorsal skeleton the structure of the present form is simple and very characteristic: The similar structure of dorsal skeleton can be found in Japanese forms $H$. reniossa and $H$. regularis, though being quite different from them. On the other hand I could not ascertain the skeletal structure being really the same as in $H$. simplex, so I will record here it as a form of the genus, until a good series of specimens obtained. If the absence of the ventrolateral plates is a constant feature for the present form, it may be a distinct species, new to science.

The description is as follows:

Disc small, rays rather obtuse, not gradually tapering to the tip, 5 in number. Dorsal plates rather uniform in size and subquadrate in form, excavated for papular areas. Carinal series indistinct. Dorsal spines small, 3 to 6 for each 
plate, encircling papular areas. The papular areas are small and sunken, containing mostly a single papula in each.

Marginal plates very distinct, arranged in regular longiseries. The superomarginals are each opposite to the inferomarginals. The superomarginals are larger than the adjacent dorsolaterals, subcordate in form, 15 in number in a ray. At the arm base the 2 of them abruptly bend upward, where a very small triangular intermarginal area is formed, containing 2 small plates. The inferomarginals are directly in contact with the superomarginals, subequal in size to the latter. These plates bear each 4 to 3 (2) spinelets similar to those of the dorsolaterals. Intermarginal papulae absent.

Ventrolateral plates entirely wanting. The fact is very characteristic of the present form. No ventrolateral papular areas.

Adambulacral plates spaced, transversely elongated, the 5 corresponding to the 4 of inferomarginal plates. The armature consists of a transverse series of 3 subambulacral spines bluntly pointed. The innermost ones standing at the furrow edge are the longest, then gradually decrease in size from furrow outerward. Deep in furrow is found a much smaller spinelet in each.

Mouth plates each with 3 (2) blunt spines along furrow margin, gradually increasing in size oralward. In the ventral surface, a single spine is found, but not usually, absent in some plates. Deep in furrow, succeeding to the series of adambulacral furrow spines, are found 2 much smaller spinelets.

Madreporite circular, situated midway between the centre of disc and the margin, encircled by small spinelets similar to the adjacent dorsolaterals. Three similar spinelets occur on the surface of madreporite.

Loc. Cape Town (A gift of a native school boy).

\section{LITERATURE CITED}

Clark, H. L. 1923. The Echinoderm Fauna of South Africa. Ann. South African Mus., vol. 13, pt. 7, pp. $221-435,16$ pls.

FISHER, W. K. 1940. Asteroidea. Discovery Reports, vol. 20, pp. 69_306, 23 pls.

KoeHLER, R. 1920. Echinodermata Asteroidea. Australasian Antarctic Expedition 1911-14, ser. C, vol. 8 , pt. 1, 308 pp., 75 pls.

\section{PLATE I}

Fig. 1. Dorsal side of Asterina dyscrita Clark. About $2.5 \times$.

Fig. 2. Ventral side of Asterina dyscrita ClARK. About $2.5 \times$.

Fig. 3. Dorsal side of Henricia sp. About $3 \times$.

Fig. 4. Ventral side of Henricia sp. About $3 \times$.

Fig. 5. Ventral side of Odontaster validus KoEHLER. About $2 \times$.

Fig. 6. Dorsal side of Odontaster validus KOEHLER. About $2 \times$. 
Plate I
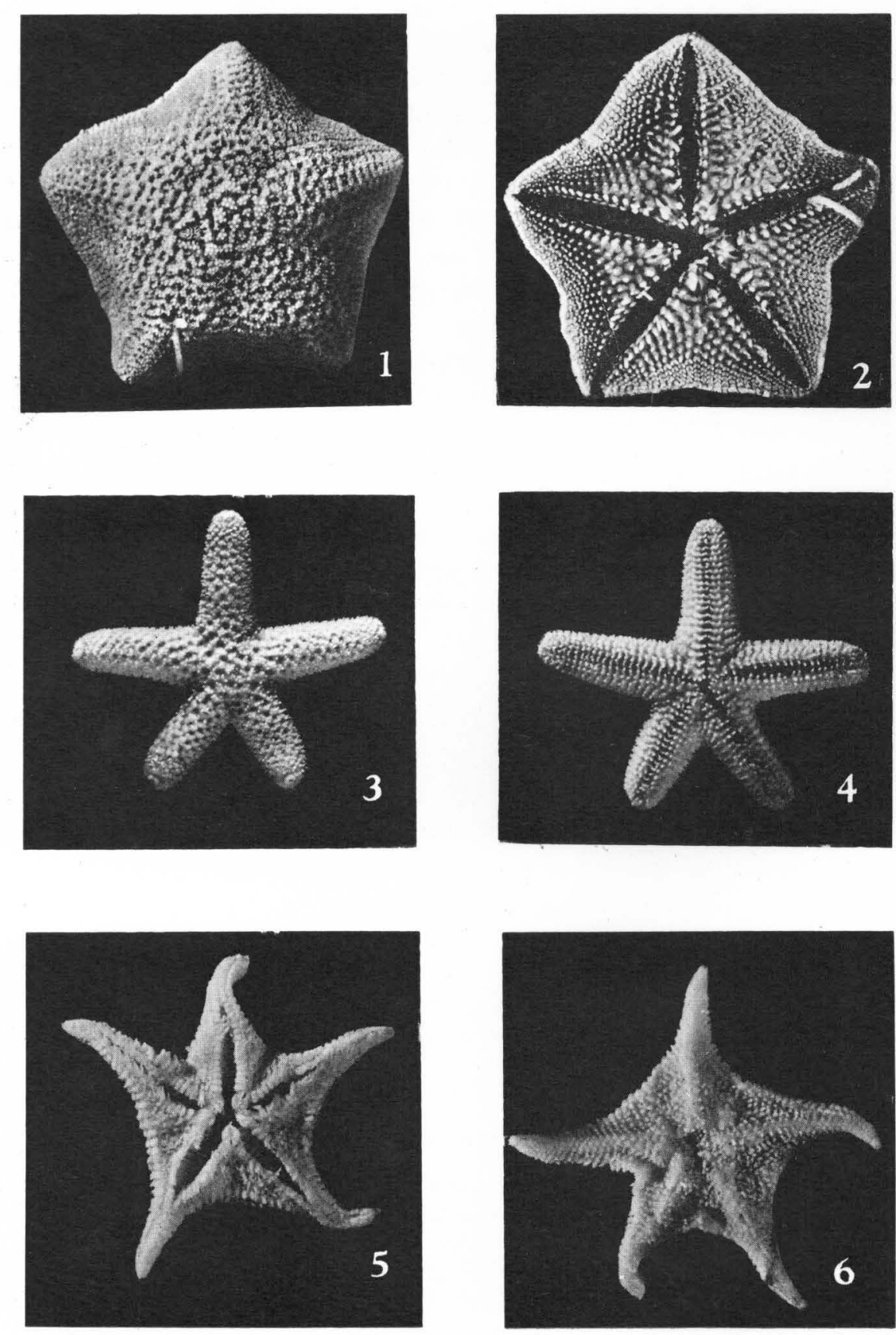


\section{BIOLOGICAL RESULTS}

$\mathrm{OF}$

\section{THE JAPANESE ANTARCTIC RESEARCH EXPEDITION}

1. Tanita, Senji: Sponges. $8 \mathrm{pp}$.

May 1959

2. NAKASEKo, Kojiro: On Superfamily Liosphaericae (Radiolaria) from sediments in the sea near Antarctica (On Radiolaria from sediments in the sea near Antarctica. Part 1). 13 pp., 3 pls.

May 1959

3. Hirano, Minoru: Notes on some algae from the Antarctic collected by the Japanese Antarctic Research Expedition. 13 pp., 3 pls.

May 1959

4. HataI, Kotora: A new rhynchonellid (Brachiopoda) from Antarctica. 7 pp.

May 1959

5. Tokioka, Takasi : Amaroucium erythraeum Michaelsen, a compound ascidian from the Cape Province. 6 pp.

May 1959

6. Yosir, Riozo: Collembolan fauna of the Cape Province, with special reference to the genus Seira Lubbock. $24 \mathrm{pp}$.

June 1959

7. Gamo, Sigeo: On a cumacean Crustacea (Diastylis corniculatus Hale) obtained by the Second Japanese Antarctic Research Expedition (1957-58). 7 pp.

October 1959

8. Utinomi, Huzio: Pycnogonida of the Japanese Antarctic Research Expeditions 1956-1958. $12 \mathrm{pp}$.

December 1959

9. Matsubara, Kiyomatsu and Ifai, Tamotsu: Fishes. 7 pp., 1 pl. December 1959

10. Tanaka, Otohiko: Pelagic Copepoda. 95 pp., 40 pls. March 1960

11. Uchio, Takayasu: Planktonic Foraminifera of the Antarctic Ocean. 9 pp., 1 pl. May 1960

12. Uchro, Takayasu: Benthonic Foraminifera of the Antarctic Ocean. 19 pp., 1 pl.

May 1960

13. Kobayasi, Yosio: An imperfect lichen found in the Antarctica. 7 pp. March 1961

14. Tuвакл, Keisuke: On some fungi isolated from the Antarctic materials. 9 pp.

March 1961

15. Soneda, Masami: On some yeasts from the Antarctic region. $1961.10 \mathrm{pp}$.

March 1961

16. Hayashi, Ryoji: Asteroidea of the Second Japanese Antarctic Research Expedition (1957-1958). 8 pp., 1 pl.

December 1961 